\section{Aviation dentistry: \\ current concepts and practice}

\author{
Y. Zadik'
}

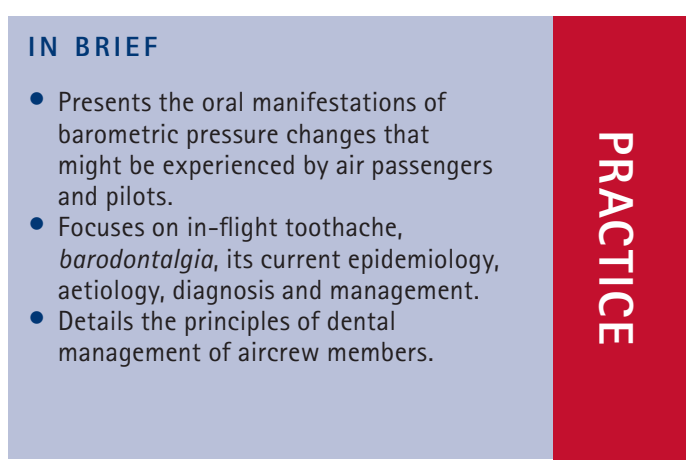

Background With the growing number of air passengers, flight attendants, leisure pilots as well as military and airline pilots, dentists may increasingly encounter flight-related oral conditions requiring treatment. Moreover, dentists should prevent the creation of in-flight hazards when treating aircrew members. The aim of this article is to introduce the concepts of aviation (aerospace) medicine and dentistry. Methods Data were gathered to cover the following issues: head and facial barotraumas (barotrauma-related headache, external otitic barotrauma, barosinusitis and barotitis-media), dental barotrauma (barometric pressure-related tooth injury), barodontalgia (barometric pressure-related oro-dental pain), and dental care for aircrews. Results and conclusions Special considerations have to be made when planning restorative, endodontic, prosthodontic and surgical treatment to an aircrew patient. This article supplies the dental practitioner with some diagnostic tools as well as treatment guidelines. Principles of prevention, periodic examination, dental-related flight restriction (grounding) and dental documentation (for forensic purposes) are described as well.

\section{INTRODUCTION}

During flight, the aircrew is responsible for the lives of the aircrew members and passengers, for successfully completing the flight, and for maintaining the aircraft in good condition. In-flight sudden incapacitation could jeopardise the flight's safety; thus, an individual's health status is an important part of the aircrew's operative fitness. ${ }^{1}$

Shortly after the innovation of modern flight, at the beginning of the twentieth century, in-flight physiologic and pathologic phenomena began to be reported, including those relating to the face and the oral cavity. Since dental and other oral problems were reported as the causes of severe in-flight pain and vertigo, incapacitation, and premature cessation of flights, ${ }^{2-6}$ guidelines for den-

\footnotetext{
Head, Zrifin Central Dental Clinic and The Center for Health Promotion and Preventive Medicine and The IDF Dental Forensic Team, Medical Corps, Israel Defense Forces, Jerusalem, Israel

Correspondence to: Dr Yehuda Zadik

Email:yzadik@gmail.com
}

\section{Refereed Paper}

Accepted 22 September 2008

DOI: $10.1038 /$ sj.bdj.2008.1121

${ }^{\circ}$ British Dental Journal 2009; 206: 11-16 tal care of aircrews have been published over the last 60 years.

Most of the previously published guidelines advised using a more interventional/non-conservative approach in treating aircrews than other populations. For example, in the World War II (WWII) era, it was recommended that all pulpless teeth in aircrew patients be removed, as well as any roots that were subjected to fracture or incomplete extraction. ${ }^{7}$ In addition, for aircrew patients, it was recommended to replace metallic restorations with plastic restorations in order to minimise the pressure in the pulp chamber that may produce odontalgia'?

However, starting from initial promises and the vision of postgraduate training in aviation dentistry more than six decades ago, ${ }^{8}$ we currently possess little knowledge on this subject and lack evidence-based guidelines for dental care of aircrew members. Moreover, this subject is rarely and only briefly discussed in dental textbooks. ${ }^{9,10}$

\section{OBJECTIVES}

With the increasing number of air passengers as well as airline and leisure pilots and their aircrew, dentists may regularly encounter flight-related oral conditions requiring immediate treatment. Moreover, dentists should prevent the creation of in-flight hazards when treating aircrew members. Since the population of aircrews is generally healthy, dental illness and hospitalisation were found to be a significant part of aircrew's morbidity. ${ }^{11}$

The aim of this article is to introduce the concepts of aviation medicine and dentistry to the dentist, and to supply the dental practitioner with some diagnostic tools as well as treatment guidelines.

\section{HEAD AND FACE BAROTRAUMA}

According to Boyle's Law, the volume of gas at constant temperature varies inversely with the surrounding pressure. The changes in gas volume inside the body's rigid cavities, associated with the changing atmospheric pressure, can cause several adverse effects, known as barotrauma. ${ }^{12}$ Barotrauma can occur during flying, diving, or hyperbaric oxygen therapy.

Head and face barotrauma include the entities of external otitic barotrauma, barotitis-media, barosinusitis, barotrauma-related headache, dental barotrauma, and barodontalgia (the 
latter two will be discussed separately). External otitic barotrauma is caused by injury to the lining mucosa of the external ear canal owing to the airtight space between an object in the outer ear canal (mostly earplugs) and the eardrum. During descent, the relative pressure in that closed cell is negative (compared with outer pressure); thus, the external layer of the tympanic membrane epithelium or of the external canal epithelium (or both) may be sucked away from the underlying tissue. Sub-epithelial hemorrhagic areas can then be formed. The process of stripping the epithelial layer may be accompanied by pain. ${ }^{3}$

First described in 1937, barotitis-media (also known as middle ear barotrauma) is an acute or chronic traumatic inflammation in the middle ear space produced by a pressure differential between the air in the tympanic cavity and that of the surrounding atmosphere. ${ }^{3}$ The rigid cavity of the middle ear space is ventilated by the one-way fluttered Auditory (Eustachian) tube, which opened by the simultaneous contraction of the tensor veli palatini and salpingopharyngeus muscles, in a positive air pressure gradient between the middle ear space and the outer one, as well as during swallowing or yawning. However, in rapid descent, the negative pressure developed in the middle ear is usually not resolved spontaneously. As a result, a partial vacuum is created and barotitis-media may result with tympanic membrane retracted, and later, haemorrhage as well as vascular engorgement occurred. The gradient is eventually relieved by the transudation of serum into the space. The symptoms of barotitis-media range from ear discomfort to intense pain, tinnitus, vertigo with nausea, and deafness. ${ }^{12}$ Barotitis-media is the most common reaction of aviators to altitude-related pressure changes with prevalence up to $9 \%$. Upper respiratory tract infection may impair the balancing function of the eustachian tube, thus predisposing the individual to barotrauma. ${ }^{3}$

Barosinusitis (also known as sinus barotrauma) is an acute or chronic inflammation of one or more of the paranasal sinuses, produced by the development of a pressure difference (usually negative) between the air in the sinus cavity and that of the surrounding atmosphere. ${ }^{3}$ Normally, there is no air pressure differential between the sinuses and the outside environment. However, when the normal sinus outflow is compromised, as may occur during upper respiratory tract inflammation, a pressure gradient is created, resulting in a vacuum effect that may be stressful to the sinus mucosal lining. The vacuum may cause mucosal edema, serosanguineous exudate, and submucosal haematoma, which may consequently cause pain, sometimes abrupt and severe, and possibly epistaxis. Ensuing pain and numbness may occur as a result of pressure on branches of the trigeminal nerve in the maxillary sinus. The incidence of barosinusitis during descent is about double that during ascent.

Berilgen and Mungen reported barotrauma-related headache in a six-case series of 15-20-minute headache episodes during ascending and descending. The authors assumed that the vacuum inside the sinus may cause damage to the ethmoid cell mucosa and trigger the ethmoid nerves (branches of the ophthalmic branch of the trigeminal nerve that innervate the mucosa on the inner surface of the sinus); thus orbital and/or peri-orbital headache occurs. In addition, barotrauma may stimulate the nociceptors on the ethmoid artery and may lead to a headache in the orbital and/or supra-orbital area by triggering the trigemino-vascular system. ${ }^{13}$

The dental relevance of non-dental head and face barotraumas follows:

1. Either barotitis-media or barosinusitis can occur and be manifested as toothache (indirect barodontalgia). ${ }^{14}$ Thus, they should appear in the differential diagnosis list of dental pain that is evoked during changes in barometric pressure

2. Several reports claimed that a relationship exists between dental malocclusion and eustachian tube dysfunction. ${ }^{15}$ Dental splint was offered as a preventive and/or therapeutic measure for barotitismedia. ${ }^{16}$ Currently, barotitis-media is usually not an indication of the need for a dental splint.

\section{DENTAL BAROTRAUMA}

\section{In-flight dental fracture}

Several reports, mostly from the WWII period, deal with fracture of restorations during high-altitude flying. ${ }^{8,17}$ The United States Air Force (USAF) symposium, held in 1946 to summarise the USAF experience during WWII, confirmed that the in-flight loss of restorations actually occurred during highaltitude flight. ${ }^{8}$ The predisposing factors for in-flight dental fracture, reported in several case reports ${ }^{17,18}$ as well as with an in vitro model, ${ }^{19}$ are the presence of preexisting leaked restorations and/or latent secondary caries lesions underneath the restoration in the affected tooth prior to exposure to the barometric changes.

\section{Reduction of prosthetic device retention}

Pressure changes in micro air bubbles in the cement layer underneath crowns can lead to a significant reduction of the prosthetic device's retention and even to dislodgement, ${ }^{20}$ especially if the crown was cemented with zinc phosphate cement. ${ }^{21-23}$

Lyons et al. studied the effect of cycling environmental pressure changes (up to $3 \mathrm{~atm}$ ) on the retention of crowns to extracted teeth. The crowns that were cemented with either zinc phosphate cement or glass ionomer cement had significantly reduced retention (in approximately $90 \%$ and 50\% of cases, respectively), whereas crowns that were cemented with resin cement did not have reduced retention after pressure cycling. ${ }^{22}$ Moreover, microleakage was detected in the zinc phosphate and glass ionomer cements after pressure cycling, whereas no microleakage was detected in the resin cement. ${ }^{23}$

Reduced barometric pressure can impair the retention of full removal dentures. However, whereas the environmental pressure is a definite factor in retaining maxillary dentures, it plays only a partial role in mandibular denture retention. ${ }^{24}$

\section{BARODONTALGIA}

Barodontalgia (previously known as Aerodontalgia), a dental pain evoked by a change in barometric pressure, in an 


\begin{tabular}{|c|c|c|c|c|c|c|}
\hline \multicolumn{2}{|c|}{ Source } & USA $^{\text {a } 8}$ & Germany ${ }^{25}$ & Spain $^{27}$ & $|s r a e|^{29}$ & Turkey $^{26}$ \\
\hline \multicolumn{2}{|c|}{ Year of publication } & 1946 & 1993 & 2004 & 2007 & 2007 \\
\hline \multicolumn{2}{|c|}{ Platform } & $\begin{array}{l}\text { high-altitude chamber } \\
\text { simulations }\end{array}$ & $\begin{array}{l}\text { high-altitude chamber } \\
\text { simulations }\end{array}$ & In-flight & In-flight & In-flight \\
\hline \multirow{7}{*}{ 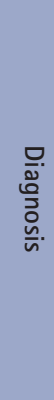 } & Recent restorative treatment & + & & & $30 \%$ & \\
\hline & Defective restoration & & & $23 \%$ & & $28 \%$ \\
\hline & Deep caries without pulp exposure & & $36 \%$ & & & $16 \%$ \\
\hline & Vital pulp exposure & + & $29 \%$ & & & \\
\hline & Pulpitis & & $14 \%$ & & $7 \%$ & $22 \%$ \\
\hline & Peri-apical periodontitis (pulp necrosis) & + & $14 \%$ & $39 \%$ & $19 \%$ & $22 \%$ \\
\hline & Barosinusitis & & & & $19 \%$ & $6 \%$ \\
\hline
\end{tabular}

otherwise asymptomatic tooth, may be severe enough to cause in-flight vertigo, incapacitation, and premature cessation of flights and altitude-chamber simulations. ${ }^{2,30}$

Data from altitude chamber simulations that took place in the USAF in the 1940s revealed that barodontalgia occurred between $0.7 \%$ and $2 \%$ of the simulations, and ranked fifth among the physiological complaints of the trainees, and third as a causative factor of premature cessation of the simulation. ${ }^{8}$ Between $0.23 \%$ and $0.3 \%$ of USAF trainees suffered from barodontalgia during altitude-chamber simulations in 1964 and 1965, respectively. ${ }^{3}$ Similarly, barodontalgia was reported in $0.26 \%$ of altitude-chamber simulations in the German Luftwaffe during the $1980 \mathrm{~s}^{25}$ and in $0.3 \%$ of the Turkish Air Force flights in the last decade. ${ }^{26}$

In a retrospective study done after WWII in the USAF, 9.5\% of American aircrews reported one or more episodes of barodontalgia in their past flights. ${ }^{8}$ Recently, 2.4\%, 8.2\%, and as high as half of 499 Spanish, 331 Israeli, and 135 Saudi Arabian and Kuwaiti Air Force aircrews, respectively, reported at least one episode of barodontalgia. ${ }^{27-29}$ In the Israeli Air Force study, the rate of barodontalgia was about 1 case per 100 flight-years. ${ }^{29}$

Barodontalgia is a symptom rather than a pathologic condition itself. Barodontalgia is usually a flare-up of preexisting sub-clinical oral-maxillofacial

\begin{tabular}{|c|c|c|}
\hline & $\begin{array}{l}\text { Direct barodontalgia owing to pulp disease with or } \\
\text { without peri-apical involvement }\end{array}$ & Indirect barodontalgia \\
\hline Cause & Pulp/peri-apical disease. & $\begin{array}{l}\text { Barosinusitis, } \\
\text { barotitis media. }\end{array}$ \\
\hline Appearance & $\begin{array}{l}\text { Pulpitis: during take-off/ascent. Pain usually appears } \\
\text { during landing at the appearance-level. } \\
\text { Peri-apical periodontitis: usually at high altitude } \\
(38,000 \mathrm{ft}) \text { during ascent or landing. } .^{40}\end{array}$ & $\begin{array}{l}\text { During landing. Pain usually } \\
\text { continues on ground. }\end{array}$ \\
\hline Symptoms & $\begin{array}{l}\text { Irreversible pulpitis: sudden sharp penetrating pain. } \\
\text { Reversible pulpitis or necrotic pulp: beating dull pain. } \\
\text { Peri-apical periodontitis: continuous strong pain, swelling. }\end{array}$ & $\begin{array}{l}\text { Toothache in upper } \\
\text { premolar/molar region. }\end{array}$ \\
\hline History & $\begin{array}{l}\text { Recent dental treatment. Recent dental sensitivity (eg to } \\
\text { cold drinks, percussion/eating). }\end{array}$ & $\begin{array}{l}\text { Present acute upper } \\
\text { respiratory infection. } \\
\text { Past sinusitis. }\end{array}$ \\
\hline $\begin{array}{l}\text { Clinical } \\
\text { findings }\end{array}$ & $\begin{array}{l}\text { Extensive caries lesions or (faulty) restoration. Acute pain } \\
\text { upon cold or percussion test. }\end{array}$ & $\begin{array}{l}\text { Pain on sinus palpation. } \\
\text { Pain upon a sharp change } \\
\text { in the head position. }\end{array}$ \\
\hline $\begin{array}{l}\text { Radiological } \\
\text { findings }\end{array}$ & $\begin{array}{l}\text { Pulpal caries lesions and/or restoration close to } \\
\text { pulp-horn. Peri-apical radiolucency. Inadequate } \\
\text { endodontic obturation. }\end{array}$ & $\begin{array}{l}\text { Opacity (fluid) on the } \\
\text { maxillary sinus image. }\end{array}$ \\
\hline
\end{tabular}

disease caused by a change in barometric pressure. Most of the common oral pathologies have been reported as possible sources of barodontalgia: dental caries, defective tooth restoration, pulpitis, pulp necrosis, apical periodontitis (jawbone cyst and granuloma), periodontal pockets, impacted teeth, and mucous retention cysts. ${ }^{8,25,29-31}$ One exception is barodontalgia manifested as referred pain from barosinusitis or barotitismedia. The latter two conditions are generated from pressure changes rather than pressure-related flare-up of preexisting conditions. Table 1 summarises the most common conditions that were reported as causes of barodontalgia.
Pulpitis is the main cause of barodontalgia from the 1940 s to date. Several suggestions have been offered to explain the mechanism underlying barodontalgia in pulpitis:

1. Direct ischaemia resulting from inflammation itself ${ }^{8}$

2. Indirect ischaemia resulting from intra-pulpal increased pressure as a result of vasodilatation and fluid diffusion to the tissue ${ }^{32}$

3. The result of intra-pulpal gas expansion. ${ }^{33}$ The gas is a by-product of acids, bases, and enzymes in the inflamed tissue

4. The result of gas leakage through the vessels because of reduced gas 
solubility. ${ }^{34}$ This theory was based on a histological view of gas bubbles on sectioned teeth that were extracted after barodontalgia. ${ }^{34}$ Bergin accepted the solubility theory, ${ }^{35}$ but Lyon et al. rejected that theory because the authors had seen gas bubbles only in 6 out of 75 teeth. ${ }^{36}$ Another argument against accepting the solubility theory is that the gas bubbles that they had seen were probably artifacts because of a faulty fixation of the histological preparations. ${ }^{37}$

Currently there is no consensus about the mechanism underlying pulpitisinduced barodontalgia.

Table 2 compares the pulp-related ('direct') barodontalgia and barotitis/ barosinusitis-induced ('indirect') barodontalgia. In contrast to some authors' arguments that the vast majority of barodontalgia cases are actually barosinusitis referred pain,,$^{10,38,39}$ in other studies, non-dental facial barotrauma was found to be a responsible for only 7\% to $19 \%$ of barodontalgia cases..$^{8,25,29}$

Previous studies have documented the difficulty of obtaining a definitive diagnosis of the causative pathology of barodontalgia ${ }^{4,8,30}$ because the clinician has to identify the offending tooth, which could be any tooth with existing restoration or endodontic treatment (often clinically accepted), and/or adjacent anatomical structures (eg maxillary sinus). Moreover, the clinician cannot reproduce the pain trigger factor (ie barometric pressure change) with ordinary dental facilities and, even in a diagnostic altitude-chamber simulation, it is sometimes impossible to reproduce the pain.

\section{PREVENTION}

Currently it seems that the incidences of in-flight dental manifestations of pressure changes are relatively low (compared with the reported incidences from the first half of the twentieth century), owing to the current inside pressurisation of airplane chambers, the highquality dental care, and the enhancement of oral health in the second half of the twentieth century. ${ }^{3,29}$

Special attention must be devoted to prevention of dental problems and to oral

\begin{tabular}{|l|l|}
\hline Table 3 Summary of principles of dental care \\
\hline Discipline & Principles \\
\hline Prevention & $\begin{array}{l}\text { - Balanced diet with regular meals, avoidance of high-energy snacks } \\
\text { - Timely oral self-care } \\
\text { - Vitality test to extensively restored teeth } \\
\text { - Special attention to defective restorations, restorations with poor } \\
\text { retention, and secondary caries lesions } \\
\text { - Rule out bruxism } \\
\text { - Panoramic radiograph }\end{array}$ \\
\hline Reriodic examination & $\begin{array}{l}\text { - Removal of all carious tissue and placement of protective cavity liner } \\
\text { before restoring }\end{array}$ \\
\hline Endodontics & $\begin{array}{l}\text { - Avoidance of direct pulp capping } \\
\text { - Reinforced temporary restoration }\end{array}$ \\
\hline Prosthodontics & $\begin{array}{l}\text { - Enhanced retention } \\
\text { - Clear speech } \\
\text { - Resin cement }\end{array}$ \\
\hline Oral surgery & $\begin{array}{l}\text { - Rule out oroantral communication } \\
\text { - Meticulous documentation }\end{array}$ \\
\hline Documentation &
\end{tabular}

Table 4 Oral conditions and dental treatments in which grounding of aircrews should be considered

\begin{tabular}{|c|c|}
\hline Disease & $\begin{array}{l}\text { Acute infection with systemic symptoms (eg elevated temperature, malaise) } \\
\text { Toothache-related sleepless nights }\end{array}$ \\
\hline Treatment/medication & $\begin{array}{l}\text { Local anaesthetic } \\
\text { Tooth extraction } \\
\text { Oral/periodontal surgery } \\
\text { NSAIDs (eg Ibuprofen, naproxen) } \\
\text { Opiates (eg paracetamol with codeine, oxycodone) } \\
\text { Systemic antimicrobial agents } \\
\text { Dental-related weakness or dizziness }\end{array}$ \\
\hline
\end{tabular}

health maintenance. Rayman emphasised the importance of healthy dental status maintenance by aircrews, in order to prevent in-flight incapacitation owing to barodontalgia (although rare), discomfort, performance decrement, and poor nutrition because of chewing difficulties, as well as prevention of dental problems in isolated locations (where professional dental providers are not available or where AIDS and hepatitis are endemic and there is increased danger of infection during dental treatment) and during long-term captivity of military aircrews. ${ }^{5}$

Because of the nature of their job, with missed meals and time zone changes, military as well as airline staff are more tempted towards high energy snacking and consuming sugar drinks. ${ }^{6}$ In addition, owing to the irregularity of their shifts and time zone changes, their daily oral self-care activities could be missed. Dentists have the responsibility to educate their patients about the importance of a healthy diet and motivate them toward maintaining meticulous oral hygiene.

\section{PERIODIC EXAMINATIONS}

Similarly, early diagnosis of initial visible and occult oral disease is of a special importance for aircrews. However, a comparison of several air forces worldwide revealed nonuniformity in the frequency and extent of periodic dental examination..$^{40}$ Currently there is no evidence-based guidelines or any consensus regarding the frequency and extent of periodic aircrews' dental examinations.

However, based on both published studies and research reports, ${ }^{18,29,31}$ special attention should be given to defective (fractured or cracked) restorations, restorations with poor retention, and secondary caries lesions. Cold-test and/or peri-apical radiographs should be performed in teeth with preexisting extensive restorations, to rule out occult pulp necrosis. ${ }^{31}$ Panoramic radiographs could be useful for revealing additional occult dental pathologies and for documentation purposes. When a panoramic radiograph is not available, peri-apical radiographs of upper and lower incisors may be of diagnostic value. ${ }^{31,41}$ Since there are several reports of high prevalence of 
bruxism among aircrews, ${ }^{42,43}$ dentists should look for signs of teeth attrition.

\section{DENTAL TREATMENT}

Similarly to the lack of consensus regarding dental examinations, there is a lack of agreement regarding dental treatment and the grounding period of aircrews for dental reasons. Most of the previously published guidelines dictated more interventional/non-conservative approachs in treating aircrews than other populations for eliminating the potential of acute symptoms in-flight, at an isolated location, or in captivity. Table 3 summaries the principles of dental care for aircrew members.

\section{Restorative dentistry}

The destructive potential of arrested or remaining carious lesions in daily life is minimal. Since the lesion is not active, progression toward the pulp tissue is unlikely. Nevertheless, as Sognnaes suggested, ${ }^{17}$ it seems that such lesions carry dangers in a pressure-changed environment and should be removed. Moreover, although there is supportive evidence for treating deep carious lesions by the indirect pulp capping technique (in which leathery/softened and wet pulpal dentine is not removed, but sealed) in the general population, ${ }^{44}$ it is not recommended for aircrews, who are daily exposed to barometric pressure changes. After carious tissue is removed, the clinician has to carefully examine the cavity floor and rule out penetration to the pulp chamber. A protective cavity liner (eg glass ionomer cement) should be applied before the cavity is restored.

\section{Endodontics}

Rossi ${ }^{45}$ contraindicated direct pulp capping in those patients, and recommended endodontic treatment in each case of suspected invasion to the pulp chamber. When performing multi-visit endodontic treatment, the dentist has to carefully apply the temporary restoration in place. In addition, he or she has to train the aircrew patient to notice whether the temporary restoration is not intact. In a pressure-changing environment, open unfilled root canals can cause facial emphysema as well as leakage of the intra-canal infected content to the peri-apex tissues. ${ }^{46,47}$

\section{Prosthodontics}

When treating aircrews, every effort should be made to enhance the retention of prosthodontic devices. From a point of view of retention as well as other considerations (eg speech), implant-supported prosthesis favors removal prosthesis. A clear distinction between $/ \mathrm{v} /$ and /f/, and between /s/ and /sh/ should be maintained in cases of extensive incisors rehabilitation. ${ }^{45}$ Resin cement should be used when treating patients who are subjected to pressure changes. ${ }^{22}$

\section{Oral surgery}

When extracting a posterior upper tooth, the dentist has to rule out the existence of oroantral communication. Oroantral communication can lead to sinusitis ${ }^{48}$ and to adverse potential consequences upon exposure to a pressure-changing environment. When oroantral communication is diagnosed, referral to an oral surgeon for its closure is indicated. ${ }^{49}$

\section{FLIGHT RESTRICTION}

Flight restriction (grounding) of a patient is required when interference in the flight capabilities of the aircrew member is suspected. Some medications can cause dizziness or lack of concentration (eg analgesics) whereas others can cause diarrhoea (eg antibiotics). Moreover, grounding of aircrew members while they receive antibiotics is also directly related to the fact that the pilot has a medical condition requiring the use of antibiotics.

Intra-oral pressure changes several hours after tooth extraction or other oral/periodontal surgery can take out the blood clot and cause intra-oral bleeding, with obvious interference to normal functioning (especially clear speaking). Moreover, in a pressure-changing environment, the risk of emphysema can be increased as well. ${ }^{50}$ Another reason for grounding aircrew after dental extractions is that facial swelling can prevent jet and helicopter pilots from wearing helmets comfortably. ${ }^{51}$ In cases of oroantral communication, because pressure changes can interfere with such wound healing, ${ }^{48}$ grounding should be advised until healing is evident.

Oral conditions and dental treatments in which grounding of aircrews should be considered are listed in Table 4 . The usual restriction time is 24 to 72 hours, until symptoms subside, medication ceases (or at least until it can be verified that there is no diarrhoea), stabilisation of blood clot, etc. To avoid in-flight barodontalgia, Rossi ${ }^{45}$ recommends the grounding of military aircrews from time of diagnosing the need for endodontic treatment until the treatment is completed. Since dental pain often interferes with sleeping, the dentist should advise the aircrew to ground themselves until pain relief is achieved and the patient can sleep well. Consultation with a flight surgeon is required in the cases listed in Table 4 and when there is doubt.

It is reasonable therefore that an ambulatory dental appointment should be scheduled for a date with a sufficient time interval before the next planned flight (eg weekend holiday). Although routine dental restorative treatment does not require grounding, recent restorative treatment was reported as a major cause of barodontalgia (Table 1). At the time of planning treatment, dentists must notify their aircrew patients (and even patients who planned a flight) about the post-operative flight consequences and restrictions.

\section{DOCUMENTATION}

Available updated dental records are most useful for identification purposes in cases of air crashes. Since the victims' bodies in air crashes are often burnt, identification by fingerprints cannot be used; identification by DNA-profile analysis may be used but with difficulty and is time consuming. Moreover, often with leisure pilots (in contrast to professional military or airline pilots), no antemortem fingerprint records are available. Dental comparison is often the primary method of identifying disaster victims due to the high likelihood of dental anatomy preservation in traumatic deaths (up to $1600^{\circ} \mathrm{C}$ )..$^{52}$ The surviving dental arches can be immediately used for identification purposes, provided there are available antemortem dental records. An updated panoramic radiograph is the preferred method for comparison with the postmortem dental arch. ${ }^{41}$ Reports from the USAF demonstrated that an (antemortem) panoramic 
radiograph, combined with intra-oral photographs (obtained by instant camera such as Polaroid), was the most efficient method for both oral health surveys and identification. ${ }^{53}$ With every aircrew patient, there is special importance in maintaining proper up-to-date documentation of oral status and the dental treatments performed.

\section{SUMMARY}

Aircrew patients as well as air passengers often challenge the dentist in treating several flight-related conditions. This article described these conditions and provided the dentists with some useful tools and guidelines.

The author thanks Steve Manch (Rehovot, Israel) for his editorial assistance.

1. Clark J B. Risk assessment and clinical aeromedical decision-making. Aviat Space Environ Med 1993; 64: 741-747.

2. Eidelman D. Vertigo of dental origin: case reports. Aviat Space Environ Med 1981; 52: 122-124.

3. Hanna H H, Thomas-Yarington C. Otolaryngology in aerospace medicine. In DeHart R L (ed). Fundamentals of aerospace medicine. pp 525-536. Philadelphia: Lea and Febiger, 1985.

4. Senia E S, Cunningham K W, Marx R E. The diagnostic dilemma of barodontalgia: report of two cases. Oral Surg Oral Med Oral Pathol 1985 60: 212-217.

5. Rayman R B. Aircrew health care maintenance. In DeHart R L (ed). Fundamentals of aerospace medicine. p 407. Philadelphia: Lea and Febiger, 1985.

6. Ellingham H K. Dentistry in the military. Br Dent J 2002; 193: 427-428.

7. Dimas-Aruti F M. Aviation dentistry. Dent Surv 1949; 25: 357.

8. Kennebeck R, Knudtzon K F, Goldhush A A. Symposium on problems of aviation dentistry. J Am Dent Assoc 1946; 33: 827-844.

9. Ingle J I, Dudley H G. Differential diagnosis and treatment of dental pain. In Ingle J I, Bakland L K (eds). Endodontics, 4th ed. p 444. Baltimore: Williams and Wilkins, 1994.

10. Mumford J M. Pain from the periodontal tissues. In: Orofacial pain, 3rd ed. pp 234-235. Edinburgh: Churchill Livingstone, 1982.

11. Hoiberg A, Blood C. Age-specific morbidity among Navy pilots. Aviat Space Environ Med 1983; 54: 912-918.

12. Stewart T W Jr. Common otolaryngologic problems of flying. Am Fam Physician 1979; 19: 113-119.

13. Berilgen M S, Mungen B. Headache associated with airplane travel: report of six cases.
Cephalalgia 2006; 26: 707-711.

14. Garges L M. Maxillary sinus barotrauma: case report and review. Aviat Space Environ Med 1985; 56: 796-802.

15. McDonnell J P, Needleman H L, Charchut S, Allred $\mathrm{E} N$ et al. The relationship between dental overbite and eustachian tube dysfunction. Laryngoscope 2001; 111: 310-316.

16. Bierman H R, Brickman I W. The relationship of dental malocclusion to vacuum-otitis media and the use of dental splints during descent from altitudes. Ann Otol Rhinol Laryngol 1946; 55: 5-12.

17. Sognnaes R F. Further studies of aviation dentistry. Acta Odonto/ Scand 1946: 7: 165-173.

18. Zadik Y, Einy S, Pokroy R, Bar Dayan Y, Goldstein L. Dental fractures on acute exposure to high altitude. Aviat Space Environ Med 2006; 77: 654-657.

19. Calder I M, Ramsey J D. Ondontecrexis - the effects of rapid decompression on restored teeth. J Dent 1983; 11: 318-323.

20. Jagger R G, Jackson S J, Jagger D C. In at the deep end - an insight into scuba diving and related dental problems for the GDP. Br Dent J 1997; 183: 380-382.

21. Musajo F, Passi P, Girardello G B, Rusca F. The influence of environmental pressure on retentiveness of prosthetic crowns: an experimental study. Quintessence Int 1992: 23: 367-369.

22. Lyons K M, Rodda J C, Hood J A. The effect of environmental pressure changes during diving on the retentive strength of different luting agents for full cast crowns. J Prosthet Dent 1997; 78: 522-527.

23. Lyons K M, Rodda J C, Hood J A. Barodontalgia: a review, and the influence of simulated diving on microleakage and on the retention of full cast crowns. Mil Med 1999; 164: 221-227.

24. Snyder F C, Kimball H D, Bunch W B, Beaton J H. Effect of reduced atmospheric pressure upon retention of dentures. J Am Dent Assoc 1945; 32: 445-450.

25. Kollmann W. Incidence and possible causes of dental pain during simulated high altitude flights. J Endod 1993; 19: 154-159.

26. Sipahi C, Kar M S, Durmaz C. Dikicier E, Bengi U. Türk Hava Kuvvetleri uçucu personelinde görülen barodontalji prevalansý. Gülhane Týp Dergisi 2007; 49: 1-4.

27. Gonzalez Santiago Mdel M, Martinez-Sahuquillo Marquez A, Bullon-Fernandez P. Incidence of barodontalgias and their relation to oral/dental condition in personnel with responsibility in military flight. Med Oral 2004; 9: 98-105.

28. Al-Hajri W, Al-Madi E. Prevalence of barodontalgia among pilots and divers in Saudi Arabia and Kuwait. Saudi Dent J 2006; 18: 134-140.

29. Zadik Y, Chapnick L, Goldstein L. In-flight barodontalgia: analysis of 29 cases in military aircrew. Aviat Space Environ Med 2007; 78: 593-596.

30. Boggia R. The ups and downs of barodontalgia. Br Dent J 1998; 184: 99.

31. Zadik Y. Barodontalgia due to odontogenic inflammation in the jawbone. Aviat Space Environ Med 2006; 77: 864-866.

32. Harvey W. Dental pain while flying or during decompression tests. Br Dent J 1947; 82: 113-118.
33. Levy B M. Aviation dentistry. Am J Orthodont Oral Surg 1943; 29: 92-95.

34. Orban B, Ritchey B T. Toothache under conditions stimulating high altitude flight. J Am Dent Assoc 1945; 32: 145-180.

35. Bergin K G. Aviation medicine: its theory and application. p 209. Baltimore: Williams and Wilkins, 1949.

36. Lyon K M, Hood J A A, Rodda J C. Barodontalgia: a review, and the influence of simulated diving on microleakage and on the retention of full cast crowns. Mil Med 1999; 164: 222-227.

37. Stanley H R, Weaver K. A technique for the preparation of human pulpal tissues. In Finn SB (ed). Biology of the dental pulp organ, a symposium. pp 1-25. Alabama: University of Alabama Press, 1968.

38. Hutchins H C. Reynolds O E. Experimental investigation of the referred pain of aerodontalgia. J Dent Res 1947; 26: 3-8.

39. Shiller W R. Aerodontalgia under hyperbaric conditions. Oral Surg Oral Med Oral Pathol 1965; 20: 694-697.

40. Nielsen J N. A comparison of the routine medical examination of pilots in 12 air forces. Aviat Space Environ Med 1991; 62: 1090-1095.

41. Zadik Y, Somekh M. Periodic dental imaging of aircrews: a supportive opinion [Abstract]. The 2 nd Israeli National Conference of Aviation Medicine, Herzeliya, January 2006.

42. Jacobus B B. Flying personnel and occlusal/mandibular dysfunction. Aviat Space Environ Med 1984; 55: 141-142.

43. Lurie O, Zadik Y, Einy S, Tarrasch R et al. Bruxism in military pilots and non-pilots: tooth wear and psychological stress. Aviat Space Environ Med 2007; 78: 137-139.

44. Kidd E A. How 'clean' must a cavity be before restoration? Caries Res 2004; 38: 305-313.

45. Rossi D G. Health Policy Directive no. 411: Aviation and diving - dental considerations. Surgeon General, Australian Defence Force. 1995.

46. Halm T, Saghy E. The effect of changes in air pressure during flight on teeth and jaw-bones. Int Dent J 1963; 13: 569-572.

47. Verunac J J. Recurrent severe facial emphysema in a submariner. J Am Dent Assoc 1973; 87: 1192-1194.

48. Susarla S M, Blaeser B F, Magalnick D. Third molar surgery and associated complications. Oral Maxillofac Surg Clin North Am 2003; 15: 177-186.

49. Zadik Y, Einy S. Aviation dentistry. In Goldstein L (ed). Aviation medicine. pp 197-208. The Publishing House of Israeli Ministry of Defense, 2006.

50. Wilson G A, Galle S, Greene C. Subcutaneous emphysema after extraction of maxillary teeth: report of a case. J Am Dent Assoc 1983; 106: 836-837.

51. Gibbons A J. In-flight oral-facial pain. Br Dent J 2003; 194: 5.

52. Smith A. Disaster victim identification of military aircrew, 1945-2002. Aviat Space Environ Med 2003; 74: 1198-1200.

53. Meister F Jr, Simpson J, Davies E E. Oral health of airmen: analysis of panoramic radiographic and Polaroid photographic survey. J Am Dent Assoc 1977; 94: 335-339. 